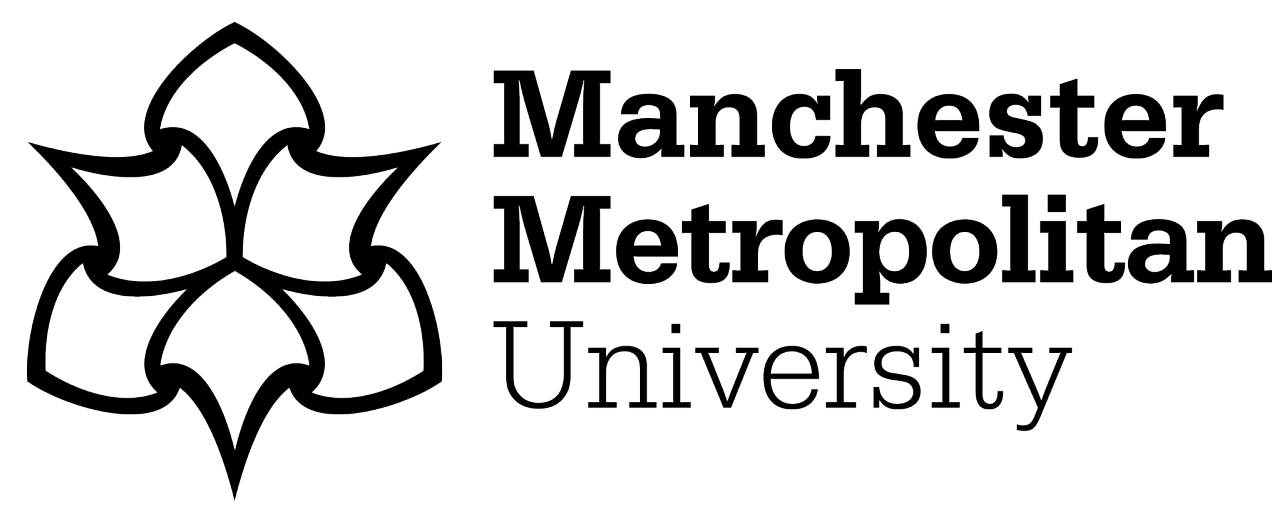

Papadopoulos, Orestis (2016) Economic crisis and youth unemployment: Comparing Greece and Ireland. European Journal of Industrial Relations, 22 (4). pp. 409-426. ISSN 0959-6801

Downloaded from: https://e-space.mmu.ac.uk/623795/

Version: Accepted Version

Publisher: SAGE Publications

DOI: https://doi.org/10.1177/0959680116632326

Please cite the published version 


\title{
Economic crisis and youth unemployment: Comparing Greece and Ireland
}

\author{
Orestis Papadopoulos
}

Keele University, UK

\begin{abstract}
Both Greece and Ireland have long suffered high youth unemployment rates and have been pressured to restructure their employment and social systems under the European Employment Strategy. Problems were aggravated by the harsh conditions imposed by the Troika following bail-outs. Yet there was significant divergence in youth employment outcomes between Greece and Ireland despite a convergence of policies. In Ireland, tighter conditionality of benefits and stronger 'activation' were already on the agenda of the social actors, so their implementation was not forcefully contested. In Greece, the lack of effective social protection made it difficult for successive governments to build support for flexibilization, and the escalating insecurity of young Greeks and their families gave rise to social unrest and political instability. This contrast leads to a reappraisal of the convergence-divergence debate.
\end{abstract}

\section{Keywords}

Economic crisis, European Union, Greece, Ireland neoliberalism, policy implementation, youth unemployment

\section{Introduction}

Since the 2008 economic crisis, young Europeans have faced rising unemployment rates, widespread insecurity and social exclusion (Eurostat, 2015b). While many European Union (EU) documents on youth unemployment prescribe 'flexicurity', post-crisis responses have leaned towards flexibility rather than security (Heyes, 2013: 82-83). Initiatives such as Youth Opportunities and the Youth Guarantee emphasize improving young people's access to the labour market through supply-side reforms (reduction in wage and non-wage costs) (European Commission, 2010b). Despite claims that structural reforms will trigger growth, critics (Lehndorff, 2015; Vaughan-Whitehead,

\footnotetext{
Corresponding author:

Orestis Papadopoulos, Keele Management School, Keele University, Staffordshire ST5 5BG, UK.

Email: o.papadopoulos@keele.ac.uk
} 
2015) contend that austerity and deregulation have deepened the recession and led to high unemployment, especially among youth. Key features of the 'European Social Model' (ESM) including social and employment protections for the most vulnerable young people have been particularly affected by the crisis measures.

This article examines Greece and Ireland, both of which experienced very high youth unemployment rates and were strongly pressured to restructure their labour and social systems in line with neoliberal ideas. Have their responses to similar pressures been translated into similar outcomes? Recent developments such as high economic and employment growth and exit from fiscal programmes in Ireland, and the continuing recession and a third Memorandum of Understanding (MoU) in Greece, cast doubts on the assumption that convergence will result from similar policies. International actors (creditors) feel strongly that Ireland was much more committed to the implementation of the reforms and took 'ownership' of the adjustment programmes, while Greece lagged behind, incapable of delivering proposed reforms or complying with its commitments (European Commission, 2015). Recent accounts (Alfonso et al., 2015; DellepianeAvellaneda and Hardiman, 2015) have emphasized factors such as interest intermediation, government approaches to social dialogue and different degrees of reform implementation capacities in order to explain diverse policy outcomes.

This article juxtaposes the two cases and sheds light on how similar policy recipes like the European Employment Strategy (EES) and the neoliberal paradigm have shaped youth employment policy. I distinguish between the substantive content of policies, their implementation (processes that mediate between policies and impact) and their impact (outcome). Previous studies have sought a definite answer on the convergence-divergence debate, downplaying the likelihood that these two trends can develop concurrently and at different policy levels; I argue by contrast that we may witness convergence and divergence at the same time.

After reviewing the current literature and outlining the research methods used, I present the pre-crisis and post-crisis youth employment policies, implementation processes and outcomes in both countries. The contribution to current debates is then outlined.

\section{Beyond convergence and divergence}

Given the magnitude of the crisis and the 'new economic governance' of the EU, how far do national institutional differences still define crisis responses? Proponents of capitalist diversity argue that national responses to external pressures reaffirm existing institutional patterns and interactions, preventing a 'monolithic' path of neoliberal convergence. Madsen et al. (2013: 341) have measured the extent to which European employment policies (flexicurity) have been implemented in countries with different youth employment regimes, arguing that national variation still defines the implementation of EU policies. Chung et al. (2012: 312), examining government measures to tackle youth unemployment in Spain, the Netherlands and Sweden, concluded that although convergence towards a supply-side paradigm was dominant, Sweden introduced protection measures for young people deviating in that respect from the other two. Yet institutional accounts (Thelen, 2012: 145-148), while recognizing that liberalization exerts 
similar pressures on different models of capitalism, argue that different pathways (such as dualization or flexicurity) still receive priority.

By contrast, 'convergence' accounts suggest that different models of capitalism increasingly adopt a similar neoliberal-inspired trajectory even if they follow different paths to that end. Heyes (2013: 82) argues that although the pace of liberalization has varied across different EU countries, the deregulation trajectory has everywhere been reinforced. Hermann (2014: 8-10) similarly believes that institutional variation or complementarity played a minor role in the selection of crisis measures in European countries, as the majority moved in a neoliberal direction although the pace and extent differed.

However, Hay and Wincott (2012) suggest that the convergence and divergence debate should be revised: the two opposite poles may coexist at different levels. By distinguishing between different possible convergence dimensions, they point out that there is likelihood for convergence in policy trajectory but divergence in ideas, processes of implementation and outcomes. Previous research (Papadopoulos, 2014: 15-17) showed that Greece and Ireland differ in the extent to which the neoliberal paradigm has been incorporated into youth unemployment debates because of the contrasting ideational frameworks of their social partners. Building on this work and within the framework proposed by Hay and Wincott, I focus here on three key dimensions: substantive content of policies, implementation processes and impact (outcome). Within this framework, both commonalities among capitalist countries in terms of policy pressures for convergence and divergence, reflecting the influence of contextual factors including different implementation processes, can be traced and analysed.

By applying such a theoretical insight to convergence and divergence, I conceptualize neoliberalism not as a fixed end point towards which different countries are moving but rather as a process whose processual conception leaves open space for varied and uneven outcomes. As Peck and Tickell (2002: 395-396) note, perceiving neoliberalism as a process and accepting its contingent nature allow for different outcomes. Even similar neoliberal trajectories may be compatible with further divergence in countries' position on the spectrum of capitalist diversity.

\section{Greek and Irish models of capitalism and their policy trajectories before and since the crisis}

There have been various attempts to categorize Greek capitalism within the typologies of varieties of capitalism and welfare states. It is also classified, together with Spain, Portugal and Italy, as a Southern European model, distinguishable from the 'pure' of coordinated market economies (CMEs) and liberal market economies (LMEs). Although differences exist between them, Southern countries share common institutional characteristics emanating from similar modes of post-war economic and political development. This model includes late industrialization, the important role of the state in economic development and an industrial relations system inclined towards conflict rather than cooperation (Symeonidou, 1996: 83). Employment regimes have provided high levels of employment protection legislation (EPL) for 'insiders', combined with extensive 
self-employment and informality. In Greece, despite stronger labour protection than in most other Western countries, informal and in some cases illegal practices dominated the youth labour market (Seferiades, 2003). Southern European welfare states have shared some characteristics including families substituting for the limited state-sponsored social protection. The Greek welfare state was consolidated during the 1980s and 1990s, but fragmentation in social provision hindered the application of a 'universalistic social citizenship' (Karamessini, 2015b: 240). Thus, there is little social assistance outside the predominant insurance-based benefit scheme, which excludes those without contributions records (young people) (Matsaganis et al., 2003: 643-645). Southern countries have also displayed a noticeable lack of administrative capacity to trigger policy innovation and social reforms, with extensive clientelism and nepotism (Featherstone, 2011: 197-198). In Greece, such features, combined with low social concertation and high political and industrial conflict, result in the social partners' historical inability to conclude social pacts (Karamessini, 2009).

Unlike Greece, Ireland - with its open economy, export-led growth, low corporate tax regime and low investment in health, social care and community services - may be categorized under the LME label (Wickham, 2012: 59-63). Its labour market arrangements are informed by the liberal model of high flexibility with a lack of 'rigidities'. This is exemplified by flexible youth employment practices, including lower wages. However, some accounts (Dukelow and Considine, 2014; Teague and Donaghey, 2009) identify the 1987 launch of social partnership in Ireland as a shift towards a neo-corporatist model where liberalization trends in economic policy were counterbalanced by processes of social expansion and coordinated wage formation. As Daly and Yeates (2003: 94) point out, the Irish welfare state followed an expansionary and inclusive trajectory under tripartite social dialogue in contrast to retrenchment in the United Kingdom. The importance of social partnership lies in the development of an arena where social issues were discussed and agreed upon with the active participation of trade unions. The objective of that model, labelled 'supply-side corporatism', was to supplement the Irish political system with a mechanism through which distributional conflicts in a neoliberal environment could be absorbed through mutually beneficial and constraining agreements. So, despite the existence of some assistance through means-tested support and activation programmes, Irish social protection deviates from solidaristic forms of welfare provision and indicates a market-minded and lean welfare state (Teague and Donaghey, 2009: 62).

One may therefore expect that Greece and Ireland will respond differently to calls for flexicurity as they exhibit different models of capitalism and welfare state and have different industrial relations systems. The Irish model can be considered more susceptible to policies such as high flexibility, and some form of social protection for uninsured persons, highly centralized coordination between the social actors and high expenditure on active labour market policies (ALMPs) can mesh with the flexicurity paradigm articulated in the policy orientation of the EES. On the other hand, the Greek model with high employment protection, lack of social provision, traditionally low activation policies and problematic development of social coordination creates a more contested social context, as both flexibility and security need substantial improvement. Hence, the institutional and political features of Greece and Ireland can be expected to mediate differently the austerity-driven reforms imposed by the Troika. 


\section{Methods}

This article stems from a larger project on youth unemployment in Greece and Ireland, in which I interviewed national actors and examined EU, Troika and national government documents and Memoranda along with Eurostat and OECD data. The interviews (15 in Greece and 11 in Ireland) were conducted between 2010 and 2012 with officials from trade unions, employers' organizations, public agencies, research institutes and non-governmental organizations (NGOs). The interviewees held senior positions within their organizations and were responsible for social and employment issues and in some cases for youth issues. Where possible, more than one official from each organization was interviewed, to provide richer information regarding the position of the specific organization and the potential variety of stances on youth unemployment.

The interview programme started by contacting key 'gatekeepers' in Greece and Ireland and certain actors recommended as able to provide useful insights. These initial interviews led to others, either within the same organization or outside. The selection of participants was partly based on their seniority as the objective was to present the organizations' official positions on youth unemployment. Potential interviewees also needed to have extensive knowledge of the implementation of EU employment policies or to have participated in social dialogue procedures and committees with a focus on young people. The policies of the two countries, manifested in the perceptions of the social actors and by the outcomes of those policies, were analysed in order to identify the EU impact on Irish and Greek youth employment policies. Only a selection of this wider interview material has been used, referenced at appropriate points.

\section{Pre-crisis policies}

\section{Greece}

In Greece, labour market reforms from 2000 to 2005 increased temporary work, consolidated working time flexibility and reduced the cost of part-time work. The limited success of such reforms is illustrated by the prohibition of making fixed-term contracts in the public sector permanent, which reinforced the dual character of the labour market, excluding many young people from secure employment. As a result, one in three young workers was already in temporary employment by 2008 (Eurostat, 2015b). While parttime contracts remained rather low at 5.5 percent in 2007 and the overall EPL index was relatively high (2.73) in 2008, labour market flexibility was actually widespread but frequently hidden (Karamessini, 2015b: 236).

For that reason, many social actors were reluctant to embrace the official discourse that flexibility would be the 'cure' to the 'diseases' of the Greek labour market. A respondent from the GSEE (General Confederation of Greek Workers) reflected this dissatisfaction: 'the view that the Greek youth labour market was rigid did not take into account who is respecting labour laws and how many opportunities for flexible working and illegal behaviour existed, especially as far as young workers were concerned'. As a result, the discussion on flexicurity among the social partners brought no concrete 
outcome and GSEE left the negotiating table twice in 2007, disagreeing with further flexibilization (Kwiatkiewicz, 2011: 13).

Despite proposals in the EES to increase protection for 'outsiders', Greece continued on the path of low social protection, manifested in low net replacement rates (the proportion of net income in work that is maintained after job loss) of around 50 percent of the minimum wage, limited duration and low coverage (36\%). The very limited government response to calls for stronger social assistance is explained by the economic dependence of many young people on their families. A senior officer at the GSEVEE (Hellenic Confederation of Professionals, Craftsmen and Merchants) described the crucial role of the Greek family as follows:

we don't have a social wage in Greece. It's all up to how much help you will get from your family. Its protective role used to help young people to prolong their job search and not to take up any job.

This correlation, however perverse and unsustainable, was important in explaining the continuity in 'familistic' welfare provision despite the increasing financial strain felt by many Greek families since the 1990s.

In response to the EES and within the spirit of flexicurity, Greece did introduce ALMPs to subsidize labour costs for those aged 16-25 years and launched a new accreditation system for vocational training (OECD, 2010: 159-164). But the financial resources were limited and even declined; hence, these programmes provided limited support to young people whose participation in training and education programmes fell from 39.7 in 1999 to 32 percent in 2007 (OECD, 2009). Subsequently, the overall activation expenditure in Greece remained rather low, reaching only 0.2 percent of gross domestic product (GDP) in 2009 (OECD, 2009). In an attempt to explain the low impact of those programmes, a senior officer at the OAED (Manpower Employment Organization) stated that 'many of these [programmes] were heavily exploited by politicians and the state apparatus in order to gain electoral support by politically manipulating the beneficiaries'. The underdeveloped and clientelistic administrative structures seemed to have contributed to the low effectiveness of those programmes, as expected.

\section{Ireland}

In stark contrast, Ireland placed particular focus on ALMPs as recommended by the EES. Expenditure on ALMPs as a share of all labour market policies (41.4\% in 2005), ALMP expenditure per unemployed person (27.4\% in 2005) and overall expenditure of ALMPs as a proportion of GDP $(0.9 \%$ in 2009$)$ confirm the opposite direction taken by the country (OECD, 2009). The above numbers also reflect differences in the implementation processes. In Ireland, ALMPs were coordinated through social partnership, with the active involvement of social actors in formulating youth employment policy and without the reported clientelism, corruption or cleavages seen in Greece.

As the Irish youth employment regime was already flexible (EPL strictness was already low for both regular and temporary contracts), there was little pressure for largescale reforms. The social partners agreed to maintain the already flexible employment 
regime and trade unions merely called, successfully, for more employment rights and coordinated internal flexibility for outsiders. Social dialogue in Ireland, through successive social partnership agreements from 1987, played a crucial role in facilitating the flexicurity-type discourse (Dobbins, 2009). For instance, the 2006 agreement 'Towards 2016 ' proposed a life-cycle approach for young workers - an integrated set of policies where access to employment, skills enhancement, conditional income support and secure transitions are facilitated - so that a balance between security and flexibility could be achieved.

The existence of means-tested social provision in Ireland also facilitated an integrated approach to the principles of flexicurity. The introduction of income maintenance schemes through the Jobseeker's Allowance followed the pre-existing institutional logic of the Irish system and was used to justify the introduction of tighter 'activation' for benefit claimants. With the concept of the Developmental Welfare State, introduced in 2006 by the National Economic and Social Council, more emphasis was placed on conditional social protection for young people in line with the EES and flexicurity.

Ireland improved its social expenditure (albeit slowly) and in 2007 was among the countries with the highest scores $(0.5 \%)$ in net replacement rates during a 5-year average unemployment period (Voss et al., 2011: 25). The equivalent score for Greece was 0.1 percent. As a result, the corresponding figures for severe material deprivation for those aged 16-25years in 2008 were 6.7 percent in Ireland and 14.6 percent in Greece (Eurostat, 2015b).

\section{A similar trajectory during the crisis}

After 2009, both countries faced severe fiscal challenges. In Ireland, these stemmed from the rescue of the banks, guaranteeing their liabilities in 2008; in Greece, these stemmed from unsustainable levels of public deficit and debt in 2009. As a consequence, both countries received bail-outs tied to strict fiscal adjustment programmes set out in MoUs with the Troika. The disbursements of financial support were conditional on compliance with specific requirements, including structural reforms in core employment and social policy areas.

\section{Greece}

As part of the MoUs in 2010 and 2012, Greece agreed to reforms including the dismantling of centralized collective bargaining structures and the liberalization of EPL. Changes affecting young people in particular included the introduction of a special contract $(20 \%$ below the minimum wage), a cut in the national minimum wage by 32 percent for those under 25 years, reduced notification periods for dismissals and subsequent reductions in compensation, promotion of part-time and fixed-term work and enabling the derogation of company agreements from sectoral collective agreements (Hellenic Republic Ministry of Finance, 2012). These reforms triggered widespread discontent and dissatisfaction among trade unions and left-wing parties. A respondent from PAME (AllWorkers Militant Front) described the post-crisis policies in the following way: 'we see that there is a war against young people with the aim to impoverish them so that when 
there is growth again, employers will be able to be more profitable keeping wages at humiliating levels'. Legal scholars (Yannakourou and Tsimpoukis, 2014: 340) have also criticized such reforms for discriminating against young people's rights as specified in the European Social Charter. The Economic Affairs Commissioner argued that EU law did not apply to the agreements signed between Greece and the Troika. In any case, the 'new economic governance' of the EU involves a highly interventionist approach to youth employment policy, reversing the pre-crisis pattern of respecting national autonomy and competence over labour policies.

The conditions attached to the Second Memorandum in 2012 required unemployment benefits to be reduced by 22 percent, while eligibility criteria were tightened and the duration of benefits reduced (European Commission, 2012). Social protection measures, including minimum income guarantees and extension of benefits to long-term unemployed or new entrants to the labour market, were proposed but were stalled by limited financial resources (Adam and Papatheodorou, 2015). Consequently, most young people remained excluded from social protection, while the role of the family in protecting its young members was undermined, with almost 60 percent of families 'struggling' as early as 2011.

With so little social protection for young people or long-term unemployed, labour market reforms were seen, even by centre-right politicians, as ending a mechanism that compensated inadequate social welfare. Members of parliament from both the conservative New Democracy and social-democratic Panhellenic Socialist Movement (PASOK) criticized the inappropriateness of the reforms and their effects on their electorate (Contiades, 2012). A labour market expert at the National Centre for Social Research (EKKE) explained that 'the limited political will, and progress made, towards welfare reform was linked to the absence of a national minimum guaranteed income that could legitimize politicians pursuing labour market reforms'.

Trade unions took a militant stance, mobilizing young workers and expressing public discontent. During 2011 alone, seven national strikes were organized against labour and welfare reforms, public sector cuts and austerity (Katsoridas and Lampousaki, 2013: 12). In 2014, the Communist Youth of Greece organized rallies in Athens and Thessaloniki in response to pay cuts for those aged under 25 years and to raise awareness about the exploitative character of employment and training programmes targeting young people. Consensual reforms through social dialogue have been inhibited, with the communistled PAME accusing GSEE of betraying young workers' rights by negotiating wage and non-wage reductions with employers and by agreeing short-term and low-paid employment programmes for young people. As early as 2011, the EU pointed to the slow implementation of labour market reform in Greece, urging politicians to take ownership of the programme and overcome sectional and clintelistic networks (European Commission, 2011). There was evident discomfort by some Greek social actors, mainly large employers, over the slow pace of reform and the inability of governments to implement structural reforms. A respondent from SEV (Hellenic Federation of Enterprises) stated that 'the implementation of reforms has been rather slow due to the negative effects of party politics, clientelism, lack of political will and delay'. Some scholars (Featherstone, 2011; Ladi, 2014) also point out that the 'logic of appropriateness', the degree of compatibility between external pressure for reforms and domestic values and ideas, was problematic and low in Greece, preventing politicians from implementing reforms. 
These criticisms by the EU, domestic actors and scholars relate particularly to the Greek social and political turmoil of 2010-2012, with anti-austerity protests culminating in a confrontation between memorandum and anti-memorandum forces. The political landscape was volatile: a cabinet reshuffle in July 2011, the resignation of Prime Minister George Papandreou (replaced by technocrat Loukas Papademos) and two elections in 2012 were an unfavourable context for a committed implementation of reforms. Mainstream parties (PASOK and New Democracy) feared a negative impact on their electoral results in favour of left-wing protest parties like Syriza, so they adopted blameshifting strategies (Alfonso et al., 2015: 316, 329).

\section{Ireland}

Given the already high levels of labour flexibility, Irish labour market reforms had a more limited effect. However, under Troika pressure, changes were introduced including the reduction in the minimum wage by $€ 1$ per hour in 2010 (reversed in 2011 by the new government), changes to Registered Employment Agreements (which define minimum rates of pay and conditions are binding on every worker and his or her employer in certain sectors) and extending the scope of the 'inability to pay clause' (Dundon and Hickland, 2014: 22-23). In 2009, the government imposed a significant restructuring of public sector employment relations and cuts in pay levels, resulting in the collapse of social partnership and its corporatist model of negotiated wage determination that had lasted more than two decades.

Under pressure from the Troika, Ireland introduced major institutional reforms to welfare provision, centred on the idea that unemployment protection functioned as a work 'disincentive' and therefore needed major retrenchment (European Commission, 2010a). Cuts of about 50 percent in Jobseekers Allowance and Supplementary Welfare Allowance benefits were imposed on those aged 18-21 years and 30percent for the 22-24 age group. The effect of austerity was also evident in ALMPs, as funding limits impeded any substantial initiative in tackling youth unemployment. With soaring unemployment rates, an education and training fund was launched in 2012 with the aim to provide only 1353 training and skill-development places for long-term unemployed, including young people. A labour market expert from the Economic and Social Research Institute (ESRI) assesses in a rather critical tone the interventions of that period: 'the Training Agency cut the duration of training programmes in order to increase the beneficiaries. They took a treatment that was working for most people and they cut the dose by half'.

Although Ireland suffered externally imposed institutional change, some continuity was evident as the reform agenda on young people's activation reflected domestic and consensus-driven policy-making in rationalizing the system and reducing the work 'disincentive' effects of benefits. For example, the Irish Congress of Trade Unions (ICTU, 2009) supported benefits being conditional on young people's participation in training and employment programmes. Even after the collapse of social partnership, trade unions continued to support social dialogue and sought to avoid disorderly industrial relations. They concluded two public sector agreements, the Croke Park Agreement in 2010 and Haddington Road Agreement in 2013, and one private sector protocol with an industrial 
Table I. Youth (I5-24) employment and unemployment rates, 2008-20I5. ${ }^{a}$

\begin{tabular}{|c|c|c|c|c|c|c|c|c|c|}
\hline & & 2008 & 2009 & 2010 & 2011 & 2012 & 2013 & 2014 & 2015 \\
\hline \multirow[t]{2}{*}{ EL } & Employment & 23.5 & 22.8 & 20.1 & 16.1 & 13 & 11.8 & 13.3 & NA \\
\hline & Unemployment & 21.9 & 25.7 & 33.0 & 44.7 & 55.3 & 58.3 & 52.4 & $48.6^{b}$ \\
\hline \multirow[t]{2}{*}{ IE } & Employment & 46.2 & 36.9 & 31.5 & 29.5 & 28.2 & 29 & 28.4 & NA \\
\hline & Unemployment & 13.3 & 24.0 & 27.6 & 29.1 & 30.4 & 26.8 & 23.9 & $20.6^{b}$ \\
\hline
\end{tabular}

Source: Eurostat (2015b).

aPercentage of active population aged 15-24 years.

bRate for $2015 \mathrm{Q} 3$.

peace provision, through which a series of cuts and concessions were made (Geary, 2015: 7). Although the political landscape was reshaped in Ireland with the defeat of Fianna Fáil in 2011, electoral volatility on the Greek scale (four elections and three prime ministers in 3 years) did not occur in Ireland, and Fine Gael and the Labour Party continued the austerity programme after coming to power in 2011 despite pre-election antiausterity rhetoric.

Highlighting the significance of implementation capacities for the outcome of reforms, the European Commission (2015) noted that 'at the heart of [Irish] success was the role of Irish authorities and their positive engagement with the Troika. They were proactive in putting the reform programme together, presenting their National Plan alongside their request for financial request'.

\section{Similar trajectories but diverse outcomes after 2013}

Since the imposition of austerity in 2010, the employment prospects of Greek young people have become even worse. As Table 1 illustrates, youth unemployment in 2015 Q3 stands at 48.6 percent compared with 21.9 percent in 2008; the highest rate was recorded in 2013 at around 60 percent. The employment rate of young people nearly halved over the same period. The latest data on new vacancies (February 2015) suggest almost one in two are on flexible employment contracts while many full-time contracts changed to part-time.

The economic crisis also had a significant impact on young Irish people: unemployment rates climbed from 13.3 to 30.4 percent in the 5 years to 2012 , while employment rates dropped from 46.2 to 28.2 percent. Eurostat (2015b) data indicate that in both countries temporary employment occupies a significant proportion of overall employment: in Ireland from 21.8 percent in 2007 to 35 percent in 2014 and in Greece from 24.8 to 30.2 percent. The number not in education, training or employment (NEETs) almost doubled during 2007-2012, reaching 18.7 percent in Ireland and 20.2 percent in Greece. According to the National Youth Council of Ireland (2013), that number would have been much higher if young people had not (as in Greece) emigrated; half of those who left Ireland belonged to the 15-24 age cohort, in total 165,300 during 2008-2013.

Greece has continued on a spiral of austerity-recession-austerity (Dedoussopoulos et al., 2013: 3), with GDP collapsing by 23.5 percent (see Table 2) and investment and 
Table 2. GDP growth ${ }^{\mathrm{a}}$ and gross public debt, ${ }^{\mathrm{b}}$ 2008-20I5.

\begin{tabular}{|c|c|c|c|c|c|c|c|c|c|}
\hline & & 2008 & 2009 & 2010 & 2011 & 2012 & 2013 & 2014 & 2015 \\
\hline \multirow{2}{*}{$\overline{\mathrm{EL}}$} & Growth & 0.4 & -4.4 & -5.4 & -8.9 & -6.6 & -3.9 & 0.8 & 0.5 \\
\hline & Debt & 109.4 & 126.7 & 146.2 & 172.0 & 159.4 & 177.0 & 178.6 & 180.2 \\
\hline \multirow[t]{2}{*}{ IE } & Growth & -2.6 & -6.4 & 0.3 & 2.8 & 0.3 & 0.2 & 4.8 & 3.6 \\
\hline & Debt & 42.4 & 61.8 & 86.8 & 109.3 & 120.2 & 120.0 & 109.7 & 107.1 \\
\hline
\end{tabular}

GDP: gross domestic product.

Source: Eurostat (2015a).

aPercentage; negative figures in italics.

bPercentage of GDP.

domestic demand by 13.3 and 34.9 percent, respectively, in the period 2010-2015. Even the International Monetary Fund concluded that 'fiscal consolidation' had overdosed in Greece, with negative consequences for its macroeconomic prospects. The Irish economy, after a severe recession in 2008-2009, witnessed economic growth of around 4.8 percent in 2014 and 3.6 percent in 2015 , while government debt fell slightly after 2013 and youth unemployment declined after 2012. Long-term youth unemployment in Greece continues to rise, reaching 31.5 percent in 2014 from 18.9 percent in 2011; in Ireland, there was a decrease from 13.4 percent in 2011 to 9.2 percent in 2013. The NEET rate has also declined in Ireland by around 5 percent in the last 2 years, while in Greece it has remained stubbornly high (almost 2 out of 10 young people). Although social exclusion indicators, such as severe material deprivation, increased steeply for those aged 15-24 years in both countries from 2007 to 2012 (in Ireland from 5.1\% to $13.3 \%$ and in Greece from $14.6 \%$ to $26.1 \%$ ), in Ireland the rate has since declined by around 2 percent, while in Greece it has risen by the same magnitude.

\section{Discussion}

The findings suggest that the pre-existing Irish framework of flexible labour markets, means-tested social assistance and consensual policy-making fitted the flexicurity rationale which dominated the EES, enabling the social partners to reach consensus on youth employment policy. The latter was informed by a flexicurity-type discourse, underpinned by the creation of a developmental welfare state which was assumed to strike a balance between security and flexibility. But the Greek institutional framework of low social protection, limited expenditure on activation and widespread (informal) flexibility for outsiders rendered EES calls for flexicurity inapplicable. Limited coordination capacities, coupled with corruption, administrative inertia and a 'familist' welfare tradition, were in conflict with core recommendations of the EES such as provision of social assistance to 'outsiders' and increased coordination between the social partners in youth employment policy. Thus, Ireland achieved better scores than Greece on many flexicurity indicators. So, despite common pressures, resilient institutional constellations tied to different capitalist models and diverse industrial relations traditions sustained diversity. 
After the crisis, the two countries implemented similar neoliberal policy reforms, concentrated on labour market flexibility for both 'outsiders' and 'insiders', diminished welfare protection, pay cuts and significant containment of training and education spending. Consequently, very little space was left for policy diversity that previous accounts (Thelen, 2012) had envisaged, while core elements of the pre-crisis social models were seriously eroded. Even Ireland departed from a pattern of 'expansionary drift' articulated in the flexicurity discourse and aligned its post-crisis system with neoliberal diagnoses and remedies (Dukelow, 2015: 107). Hence, we should not confuse movement in the same direction with convergence. Greece and Ireland exhibited significant disparity in reform implementation because of differences in how domestic political and social forces dealt with proposed reforms. A mainly consensual pattern, assisted by the enduring influence of social partnership, dominated Irish youth employment policy. Ireland implemented an austerity package of 9 percent of GDP before it signed the loan agreement with its creditors in 2010 and in a climate of limited political confrontation. Social discontent, electoral volatility and political instability prevented Greek governments from fully committing themselves and implementing reforms. The radical transformation of the Greek model implied in the reforms, together with the rise of anti-austerity parties, discouraged politicians from risking the full electoral cost. As a corollary, reform implementation was often interrupted while a significant section of the Greek population came to view reforms as an external imposition, not owned by Greek politicians. Therefore, Greece and Ireland differed in the processes that mediated between the substantive content of policies and their impact (outcomes), so divergence was the dominant trajectory in that area.

At the beginning of the crisis, young people in both countries faced high unemployment rates, worsening social conditions and emigration. But in Ireland the trend was reversed in 2013 with the exit from fiscal surveillance; economic growth returned and youth unemployment, social exclusion and poverty levels declined. Greece, on the other hand, not only continues under a fiscal adjustment programme, but its economy has not yet recovered and young people still face high unemployment, inactivity, poverty and social exclusion. Critical accounts (Karamessini, 2015a; Theodoropoulou and Watt, 2012) attributed this to the false presumption that internal devaluation through radical labour market reforms could boost competitiveness and export-led growth, leading to employment growth especially among the previously excluded (outsiders). Regan (2015: 19) argues that the reliance of Southern European countries like Greece on domestic demand impeded growth in a context of suppressed wages and an adjustment programme based on heavy taxation. Conversely, Ireland has been presented as an exemplar of reform implementation: a significant part was based on public expenditure cuts rather than increased taxation, thus reducing the burden on domestic consumption. The maintenance of the low corporation tax regime (despite EU pressures to increase this tax) and the resulting attractiveness to large multinational companies have also been regarded as drivers for the employment improvements observed since 2013.

The traditionally inadequate social protection structures for young unemployed and new labour market entrants in Greece (Adam and Papatheodorou, 2015) deteriorated further once austerity obliterated resources for social protection and traditional (family) providers were less able to help because of pay and pension cuts. In Ireland, reforms focused on cost reduction but with more emphasis on tightening up conditionality and 
limiting the duration of benefits; therefore, some means-tested support for young people remained in place. This difference might explain why post-crisis social deprivation and exclusion levels are much worse in Greece, supporting the argument (Wickham, 2015: 142) that the effects of the crisis on Ireland were mitigated by the enduring impact of welfare transfers in alleviating poverty and maintaining some social cohesion. Since 2014, Ireland has placed increasing emphasis on ALMPs, introducing many programmes (Jobs Plus and Job Path) and restructuring some existing ones (Pathways to Work) in order to reduce youth unemployment.

Many accounts (Dukelow, 2015; Hermann, 2014) have stressed the limited space for divergence when countries with different social models have to adopt externally imposed liberalization and austerity policies, even if their extent differs. Such accounts tend to conflate different levels, not adequately considering that convergence in policy trajectory can be compatible with divergence in outcomes. Some scholars (Lehndorff, 2015; Vaughan-Whitehead, 2015) assume that fiscal adjustment policies necessarily lead to higher unemployment in all EU countries, without taking into account that these processes unfold in disparate national ways. Other authors (Heyes, 2013) recognize the influence of domestic factors on the shape and pace of reforms but pay less attention to actual episodes of neoliberalization.

This study addresses such episodes and finds that despite convergence on neoliberal youth employment policies, there has been significant variation in policy implementation and outcomes. For instance, institutional legacies in the two countries still define the degree and manner of implementation, despite significant institutional change. Although social partnership collapsed in 2009, Ireland still has a legacy of consensual, depolarized and pragmatic trade unionism that avoids militant and class-based opposition and encourages social dialogue and compromise (Geary, 2015: 14). The institutionally mediated policy implementation in Ireland meant that measures such as tighter conditionality of benefits and stronger activation were already on the agenda of social actors including trade unions, so their implementation was less contested. This undermines the assumption that policy formation and implementation was only an exogenous imposition, detached from domestic interests, concerns and interventions.

Yet in an institutional context of limited or non-existent social protection, it was very difficult for Greek governments to build any legitimacy around policies of flexibilization and tighter conditionality and duration of social support. The escalating social insecurity felt by young Greeks and their families gave rise to social unrest and political instability, hence the reluctance of the political establishment to take responsibility and implement reforms. The increasing discomfort expressed by Troika officials and the number of academic and political critiques of the problematic and slow pace of implementation demonstrate the weight that domestic political cleavages and social unrest had early in the crisis. In stark contrast, European Commission officials termed Ireland the 'poster boy for austerity', as Irish social actors supported substantial elements of reforms. Very diverse capitalist models, such as neo-corporatist liberal (Irish) and Southern European (Greek), can confront the same liberalization pressures but grow further apart because of endogenous factors.

The study makes three main contributions to the literature on state responses to the economic crisis. First, following the crisis, the substantive content of policies (trajectory) 
has been rather similar, but impact (actual effects) in terms of goal achievement is divergent: despite a common policy trajectory, Greece and Ireland have ended up further apart in outcomes. While many other accounts have pointed to increasing youth unemployment across Europe since the crisis, trends in Greece and Ireland have been uneven, making us reconsider how capitalist growth materializes differently and not synchronically in diverse contexts. Thus, while young people faced worsening employment and social insecurity in both countries, employment and unemployment rates have remained diverse. Significant wage reductions (a 19\% cut in unit labour costs during 2009-2012) in Ireland, in conjunction with its low tax regime, dovetailed with its export orientation, thus triggering youth employment growth. In Greece, steep wage reductions and flexible employment arrangements, coupled with significant tax increases and limited export capacity, hit the domestic economy and the employment prospects of young people.

The slow implementation of reforms and the policy mix selected by Greek governments has been considered an obstacle to an economic recovery that could boost the employment rates of young people. The variegated nature of that process was linked to, and embedded in, existing economic, political and institutional settings which shaped the path-dependent nature of implementation. Simplistic convergence accounts based on short-term trends in the first period of the crisis have to be dismissed. Contrary to conventional wisdom that countries either resist or adopt the neoliberal discourse and subsequently are led either to convergence or divergence, the two cases support the proposition of Hay and Wincott (2012: 176) that convergence and divergence can simultaneously exist at different levels. The implications for capitalist diversity scholarship are substantial.

Second, the empirical implications of previous research (Papadopoulos, 2014) on divergence between the youth unemployment discourses used by the Irish and Greek actors were extended and enriched by this study. The politicized and confrontational Greek youth employment debate was interwoven with escalating incidents of resistance and political confrontation, reducing government willingness to implement the reforms in the manner the Irish did. Although shared ideational templates do not necessarily lead to unchallenged political mediation processes (Hay and Wincott, 2012: 174), in both cases divergent implementation processes seem consistent and to some extent interwoven with the ideological differences over youth unemployment debates found in previous studies. Although ideological divergence on youth employment is a necessary but not sufficient requirement for policy divergence, the politicized and confrontational youth employment debates in Greece were more likely to be linked with turbulent and contested policy implementation processes even in a context of externally imposed policies.

Third, previous accounts tend to understate some explanatory variables in favour of others. But understanding the drivers as well as outcomes of crisis responses requires a multi-dimensional framework. Policy outcomes prove to be contingent on the interplay between implementation capacities, social dialogue capabilities, correspondence between growth models and policy choices and pre-existing institutional logics. Especially since the crisis, domestic political processes, economic capabilities and enduring institutional logics, despite the erosion of distinct national models, still constitute crucial variables accounting for variegated implementation and uneven results in youth employment. In framing neoliberalism as a process and not as an end point, this 
article has been able to trace, present and theorize the actual manifestation of that process, avoiding the reductionist divide articulated in many convergence and divergence accounts.

\section{Conclusion}

I have explored youth employment policies in pre-crisis and post-crisis periods in two countries with contrasting institutional, political and economic settings. I investigated how these policies were affected by external pressures such as the EES before 2008 and the requirements of the Troika since 2010 in both countries. As previous accounts point out, the two models have undergone significant institutional overhaul as features of the Irish and Greek models have either collapsed or been seriously curtailed. However, I have questioned the proposition that the shift towards neoliberal convergence equates with converging outcomes since policy implementation processes, political-social dynamics and enduring institutional logics can operate independently of the direction of change, mediating between policies and outcomes and affecting the actual impact.

The different outcomes observed in the two countries do not imply that Ireland is a success story that can easily be replicated. Two notes of caution are in order for any further study. First, significant migration outflows have occurred there since 2009, and a significant proportion of young people are still employed in precarious conditions and without the levels of social support or investment in training and education seen before the crisis. Thus, insecurity and poverty levels are still high, and it remains an open question whether economic and employment growth will obtain the quality and inclusive nature now missing in youth employment.

Second, the ongoing nature of the crisis, especially in Greece, and the volatile global economic context make prediction of future trends hazardous. The implementation of reforms in Greece accelerated since 2012 in conjunction with major political changes, including the signing of a Third MoU in August 2015 by the 'anti-memorandum' parties of Syriza and Independent Greeks that came to power in January 2015.

Young people's employment and social conditions are still affected by fluctuating political and economic developments in individual countries and do not simply follow from specific models of capitalism. The question that needs to be constantly addressed is whether future developments in EU member states and the EU will give rise to a more inclusive and protective youth employment regime in line with 'Social Europe' ideas or whether neoliberalism even in its variegated version will dominate the short- and medium-term trends.

\section{Acknowledgements}

I thank Paul Marginson, David Lyddon, Guglielmo Meardi, Steve Williams and Jason Heyes for helpful and constructive comments on an earlier version of this article. I also give my thanks to the Editor and the anonymous referees for their very insightful comments.

\section{Declaration of Conflicting Interests}

The author(s) declared no potential conflicts of interest with respect to the research, authorship, and/or publication of this article. 


\section{Funding}

The author(s) received no financial support for the research, authorship and/or publication of this article.

\section{References}

Adam S and Papatheodorou C (2015) Dismantling the feeble social protection system of Greece: Consequences of the crisis and austerity measures. In: Schubert K, Villota PD and Kuhlmann J (eds) Challenges to the European Welfare Systems. New York: Springer, pp. 271-300.

Alfonso A, Zartaloudis S and Papadopoulos Y (2015) How party linkages shape austerity politics: Clientelism and fiscal adjustment in Greece and Portugal during the Eurozone crisis. Journal of European Public Policy 22(3): 315-334.

Chung H, Bekker S and Houwing H (2012) Young people and the post-recession labour market in the context of Europe 2020. Transfer 18(3): 301-317.

Contiades X (2012) Vouleutés enantíon kommáton [Members of Parliament against parties]. Ethnos, 27 November. Available at: http:/www.ethnos.gr/eponymos/arthro/bouleutes_enantion_kommaton-63744267/

Daly M and Yeates N (2003) Common origins, different paths: Adaptation and change in social security in Britain and Ireland. Policy \& Politics 31(1): 85-97.

Dedoussopoulos A, Aranitou V, Koutentakis F and Maropoulou M (2013) Assessing the impact of memoranda on the Greek labour market and labour relations. ILO Governance Working Paper 53. Geneva: ILO.

Dellepiane-Avellaneda S and Hardiman N (2015) Fiscal politics in time: Pathways to fiscal consolidation in Ireland, Greece, Britain, and Spain, 1980-2012. European Political Science Review 7(2): 189-219.

Dobbins T (2009) Ireland: Flexicurity and industrial relations. EIRU Report. Available at: http:// www.eurofound.europa.eu/observatories/eurwork/comparative-information/national-contributions/ireland/ireland-flexicurity-and-industrial-relations

Dukelow F (2015) 'Pushing against an open door': Reinforcing the neoliberal policy paradigm in Ireland and the impact of EU intrusion. Comparative European Politics 13(1): 93-111.

Dukelow F and Considine M (2014) Between retrenchment and recalibration: The impact of austerity on the Irish Social Protection System. Journal of Sociology and Social Welfare 41(2): $55-72$.

Dundon T and Hickland E (2014) The reform of joint regulation and labour market policy during the current crisis: The Republic of Ireland (Industrial Relations and Social Dialogue). Report, DG Employment, Social Affairs \& Inclusions, Brussels, June.

European Commission (2010a) Memorandum of understanding between the European Commission and Ireland. Available at: http://www.finance.gov.ie/sites/default/files/euimfrevised.pdf

European Commission (2010b) Youth on the Move: An Initiative of the European Union. Luxembourg: Publications Office of the European Union.

European Commission (2011) The Economic Adjustment Programme for Greece: Third Review. European Economy Occasional Papers 77. Brussels: European Commission.

European Commission (2012) The Second Economic Adjustment Programme for Greece, March. European Economy Occasional Papers 94. Brussels: European Commission.

European Commission (2015) Commission assesses lessons from economic adjustment program in Ireland. Available at: http://ec.europa.eu/economy_finance/publications/eeip/pdf/ip004_ en.pdf

Eurostat (2015a) Database national accounts. Available at: http://ec.europa.eu/eurostat/web/ national-accounts/data/database 
Eurostat (2015b) Database population and social conditions: Youth. Available at: http://ec.europa. eu/eurostat/web/youth/data/database

Featherstone K (2011) The JCMS annual lecture: The Greek Sovereign Debt Crisis and EMU: A failing state in a skewed regime. Journal of Common Market Studies 49(2): 193-217.

Geary J (2015) Economic crisis, austerity and trade union responses: The Irish case in comparative perspective. European Journal of Industrial Relations. Epub ahead of print 30 November. DOI: $10.1177 / 0959680115616526$.

Hay C and Wincott D (2012) The Political Economy of European Welfare Capitalism. Basingstoke: Palgrave Macmillan.

Hellenic Republic Ministry of Finance (2012) Hellenic National Reform Programme 2012-2015. Report on the progress towards 'Europe 2020' and the implementation of the Euro plus Pact commitments', Athens, April.

Hermann C (2014) Crisis, structural reform and the dismantling of the European Social Model(s). Economic and Industrial Democracy. Epub ahead of print 17 December. DOI: 0143831 X14555708.

Heyes J (2013) Flexicurity in crisis: European labour market policies in a time of austerity. European Journal of Industrial Relations 19(1): 71-86.

Irish Congress of Trade Unions (ICTU) (2009) There is a better, fairer way. Congress 10 Point Plan for National Recovery. Available at: http://www.ictu.ie/publications/fulllist/there_is_a better_fairer_waydoc/

Karamessini M (2009) From a state-led familistic to a liberal partly de-familialized capitalism: The difficult transition of the Greek model. In: Bosch G, Lehndorff S and Rubery J (eds) European Employment Models in Flux: A Comparison of Institutional Change in Nine European Countries. Basingstoke: Palgrave Macmillan, pp. 223-246.

Karamessini M (2015a) Greece as an international test-case: Economic adjustment through a Troika/state-induced depression and social catastrophe. In: Lehndorf S (ed.) Divisive Integration: The Triumph of Failed Ideas in Europe - Revisited. Brussels: ETUI, pp. 95-126.

Karamessini M (2015b) The Greek social model: Towards a deregulated labour market and residual social protection. In: Vaughan-Whitehead D (ed.) The European Social Model in Crisis: Is Europe Losing Its Soul? Cheltenham: Edward Elgar, pp. 230-288.

Katsoridas D and Lampousaki S (2013) The strike phenomenon in Greece in 2012. Special Issue INE GSEE 38. Athens: INE GSEE.

Kwiatkiewicz A (2011) Joint Study of the European Social Partners 'The Implementation of Flexicurity and the Role of the Social Partners'. National Fichte Greece. Available at: http:// erc-online.eu/wp-content/uploads/2014/04/2011-00554-E.pdf

Ladi S (2014) Austerity politics and administrative reform: The Eurozone crisis and its impact upon Greek public administration. Comparative European Politics 12(2): 184-208.

Lehndorff S (2015) Europe's Divisive Integration: An Overview. Brussels: ETUI.

Madsen PK, Molina O, Møller J and Lozano M (2013) Labour market transitions of young workers in Nordic and southern European countries: The role of Flexicurity. Transfer 19(3): 325-343.

Matsaganis M, Ferrera M, Capucha L and Moreno L (2003) Mending nets in the South: Antipoverty policies in Greece, Italy, Portugal and Spain. Social Policy \& Administration 37(6): 639-655.

National Youth Council of Ireland (2013) Decrease in Emigration welcome but number of young people under 25 years leaving still too high. Available at: http://www.youth.ie/nyci/ Decreased-Emigration

Organisation for Economic Co-operation and Development (OECD) (2009) Social expenditure database. Available at: https://stats.oecd.org/Index.aspx?DataSet 
Organisation for Economic Co-operation and Development (OECD) (2010) Off to a Good Start? Jobs for Youth. Paris: OECD.

Papadopoulos O (2014) Youth unemployment discourses in Greece and Ireland before and during the economic crisis: Moving from divergence to 'contingent convergence'. Economic and Industrial Democracy. Epub ahead of print 3 October. DOI: 0143831X14550694.

Peck J and Tickell A (2002) Neoliberalizing space. Antipode 34(3): 380-404.

Regan A (2015) The imbalance of capitalisms in the Eurozone: Can the north and south of Europe converge? Comparative European Politics. Epub ahead of print 2 March. DOI: 10.1057/ cep.2015.5.

Seferiades S (2003) The European employment strategy against a Greek benchmark: A critique. European Journal of Industrial Relations 9(2): 189-203.

Symeonidou H (1996) Social protection in contemporary Greece. South European Society and Politics 1(3): 67-86.

Teague P and Donaghey J (2009) Why has Irish social partnership survived? British Journal of Industrial Relations 47(1): 55-78.

Thelen K (2012) Varieties of capitalism: Trajectories of liberalization and the new politics of social solidarity. Annual Review of Political Science 15: 137-159.

Theodoropoulou S and Watt A (2012) What Did They Expect? Lessons for Europe from a Retrospective Ex-ante Evaluation of the First Greek Bail Out Programme. Brussels: ETUI.

Vaughan-Whitehead D (eds) (2015) The European Social Model in Crisis: Is Europe Losing Its Soul? Cheltenham: Edward Elgar.

Voss E, Dornelas A, Wild A and Kwiatkiewicz A (2011) Social Partners and Flexicurity in Contemporary Labour Markets: Synthesis Report. Brussels: Social Partners.

Wickham J (2012) After the party's over: The Irish employment model and the paradoxes of nonlearning. In: Lehndorf S (ed.) A Triumph of Failed Ideas: European Models of Capitalism in the Crisis. Brussels: ETUI, pp. 59-77.

Wickham J (2015) Irish paradoxes: The bursting of the bubbles and the curious survival of social cohesion. In: Lehndorf S (ed.) Divisive Integration: The Triumph of Failed Ideas in Europe - Revisited. Brussels: ETUI, pp. 127-148.

Yannakourou M and Tsimpoukis C (2014) Flexibility without security and deconstruction of collective bargaining: The new paradigm of labor law in Greece. Comparative Labor Law \& Policy Journal 35(3): 331-370.

\section{Author biography}

Orestis Papadopoulos is Lecturer at the Management School, Keele University, UK. 